\title{
MYANMAR MEDIA: LEGACY AND CHALLENGES
}

\author{
MARIA OCHWAT*
}

\begin{abstract}
For nearly fifty years Myanmar was ruled by a military junta. It did not tolerate any criticism, and severely punished anyone who dared to oppose them. At the same time, it cut the country off from the rest of the world, preventing it from being informed about Burma's internal situation. The announcement of the changes came when Thein Sein's first civilian government was formed in 2011. Almost 10 years have passed since then and Myanmar, according to the Press Freedom Index, is considered to be one of the countries where freedom of speech and freedom of the media are commonly violated and journalists are often persecuted and punished. Freedom of expression is one of the pillars of a democratic society, the basis for its development and a condition for the self-fulfillment of the individual. One of the most important ways of exercising freedom of speech is through free and independent media.
\end{abstract}

The issue of respect for freedom of expression and freedom of the media must be seen in a broader context. It should be noted that there is a close link between respect for human rights and peacekeeping. Although freedom of expression, and thus freedom of the media, is one of those freedoms which may be restricted in specific situations, it cannot be done arbitrarily. Under public international law the exercise of these freedoms, since it carries with it duties and responsibilities, may be subject to such formalities, conditions, restrictions or penalties as are prescribed by law and are necessary in a democratic society, in the interests of national security, territorial integrity or public safety, for the prevention of disorder or crime, for the protection of health or morals, for the protection of the reputation or rights of others, for preventing the disclosure of information received in confidence, or for maintaining the authority and impartiality of the judiciary. The authorities of Myanmar, when introducing and maintaining restrictions on freedom of speech and media, often invoke the need to restrict freedom of speech and media for reasons of state security, protection of morality or public order. However, one can venture to say that they are in fact afraid of criticism and possible public actions against the current authorities.

Keywords: press freedom, freedom of speech, human rights, Myanmar, media, democracy, security.

Summary: 1. Myanmar media - Legacy and Challenges. 2. Outline of Myanmar's social and political situation since 1962. 3. Situation of the media until the end of 2011. 4. Media situation since 2012. 5. ReCOMmendations For Myanmar to GUARANTEE RESPECT FOR MEDia FrEedom. 6. CONCLUSION.

\section{MyanMAR MEDIA - LEgACY AND CHALLENGES}

As the European Court of Human Rights in Strasbourg stated in Handyside's judgment against the United Kingdom, "Freedom of expression is one of the pillars of a democratic society, the basis for its development and a condition for the self-fulfilment of the individual. [...] It cannot cover only information and views that are favourably received, or perceived as harmless or indifferent, but also those that insult, outrage or cause concern in the state or in a group of society. These are the requirements of pluralism, tolerance and openness without which a democratic society does not exist". ${ }^{1}$

\footnotetext{
*PhD, Wyzsza Szkola Bankowa, Poznan, Poland (mochwat@gmail.com).

${ }^{1}$ CASE OF HANDYSIDE v. THE UNITED KINGDOM (Application no. 5493/72), https://hudoc.echr.coe. int/eng\#\{“itemid":[“001-57499"]\}, (25.01.2020).
} 
Although freedom of expression, and thus freedom of the media, is one of those freedoms which may be restricted in specific situations, it cannot be done arbitrarily. Under public international law the exercise of these freedoms, since it carries with it duties and responsibilities, may be subject to such formalities, conditions, restrictions or penalties as are prescribed by law and are necessary in a democratic society, in the interests of national security, territorial integrity or public safety, for the prevention of disorder or crime, for the protection of health or morals, for the protection of the reputation or rights of others, for preventing the disclosure of information received in confidence, or for maintaining the authority and impartiality of the judiciary. ${ }^{2}$

The European Court of Human Rights in Strasbourg points out that there is no uniform concept of morality and that therefore the authorities of a given country, due to the constant exposure to the problems in question, can often better assess the requirements for "protection of morality" in their country. Therefore, the provisions of public international law allow in this regards a certain degree of discretion for individual States. However, it should be borne in mind that this freedom is not unlimited, since the restrictions or sanctions applied must be consistent with the obligation to protect freedom of expression. Thus, the assessment from the point of view of respect for freedom of expression in a given State will concern the purpose of implementing the restriction, the means used and their necessity. ${ }^{3}$

One of the most important ways of exercising freedom of speech is through free and independent media. Freedom of the media means the functioning of the press and printing without legal and political restrictions or interference by censorship. ${ }^{4}$ Press freedom is also understood as the freedom of non-printed media, such as radio, television or the Internet. ${ }^{5}$ The guarantees that should be given to the media are particularly important. Although the media may not cross certain boundaries, inter alia in the interests of protecting the reputation and rights of others, they are obliged to communicate information and ideas of public interest. The media have the task not only of communicating, the public also has the right to receive it. If it were otherwise, the media could not play an important role as a public observer. ${ }^{6}$

For nearly fifty years Myanmar was ruled by a military junta. It did not tolerate any criticism, and severely punished anyone who dared to oppose them. At the same time, it cut the country off from the rest of the world, preventing it from being informed about Burma's internal situation. The announcement of the changes came when Thein Sein's first civilian government was formed in 2011. Almost 10 years have passed since then and

\footnotetext{
${ }^{2}$ Art. 10.2, European Convention of Human Rights, p.12, https://www.echr.coe.int/Documents/Convention ENG.pdf, (30.03.2020).

${ }^{\overline{3}}$ CASE OF HANDYSIDE...

${ }^{4}$ Press, Free [w:], G.W. Sheldon, Encyclopedia of Political Thought, New York: Facts on File, Inc, 2001, p. 240-241.

${ }^{5}$ J.R. Lewis, Freedom of the Press [w:] The Human Rights Encyclopedia, J.R. Lewis, C. Skutsch, Armonk, New York, 2001, p. 721-723.

${ }^{6}$ CASE OF BLADET TROMSØ AND STENSAAS v. NORWAY (Application no. 21980/93), https://hudoc .echr.coe.int/eng\#\{“itemid“:[““001-58369”]\}, (25.01.2020).
} 
Myanmar, according to the Press Freedom Index, is considered to be one of the countries where freedom of speech and freedom of the media are commonly violated and journalists are often persecuted and punished. Hasn't then the joy of the 'Burmese Spring' turned out to be premature?

This article aims to discuss the issue of media freedom from 1962 to the end of 2019. The author argues that: "despite the promises of Thein Sein's government to respect freedom of speech, the situation has not improved, and journalists are threatened with repression in connection with their public observer mission." The article is divided into four parts. To ensure that this freedom does not remain in void -in the first part- it seems appropriate to refer to the political, social and economic situation in Myanmar from the 1962 military takeover to the present day. The second part will present the situation regarding respect for freedom of the media until the formation of Thein Sein's government in 2011, and the third part will present the situation from that event until the end of 2019. Part four will include recommendations for Myanmar to improve the situation of media freedom in the country. The right choice of methods will help to achieve this goal. The following research methods will be mainly used in the article: historical, comparative, case study, behavioural (including above all the technique of document analysis).

\section{Outline of Myanmar's social and political Situation Since 1962}

Burma's modern history is marked by several decades of military rule, major human rights violations and armed conflicts.

After 12 years of parliamentary democracy (1948-1962), ${ }^{7}$ on March 2, 1962 a coup d'état took place, as a result of which a military junta, headed by General Ne Win, took over the state government. This coup was a motivated by the desire to protect the state from the threat of breakdown due to ethnic conflicts and, at the same time, to abandon the incompetent and corrupt civilian rule and to strengthen the socialist economy, while abandoning foreign capital. ${ }^{8}$

As they claimed: the man will not "[...] be set free from social evils as long as pernicious economic systems exist in which man exploits man and lives on the fat of such appropriation". In their opinion, creating such a reality is possible "only when exploitation of man by man is brought to an end and a socialist economy based on justice is established; only then can all people, irrespective of race or religion, be emancipated from all social evils and set free from anxieties over food, clothing and shelter, and from inability to resist evil, for an empty stomach is not conducive to wholesome morality, as the Burmese saying goes; only then can an affluent stage of social development be reached and all people be happy and healthy in mind and body". ${ }^{9}$ They announced the

\footnotetext{
${ }^{7}$ H. James, Security and Sustainable Development in Myanmar, Routledge Taylor \& Francis Group, London and New York, 2005, p.3.

${ }^{8}$ D.I. Steinberg, Burma/Myanmar what everyone needs to know, Oxford University Press, 2010, p.63.

${ }^{9}$ The Burmese Way to Socialism, https://www.burmalibrary.org/sites/burmalibrary.org/files/obl/docs/The _Burmese_Way_to_Socialism.htm, (10.02.2020).
} 
elimination of, among other "fraudulent practices, profit motive, easy living, parasitism, shirking and selfishness", "bogus piety and hypocritical religiosity", bureaucracy, as well as strengthening the armed forces, modernising agricultural production, which is the basis of the national economy, solidarity of all ethnic minorities or introducing mainstream primary education. ${ }^{10}$ In practice, the programme has proved a complete failure, leading the country into economic ruin and isolation from the world. ${ }^{11}$ There was only one party in the state, The Burma Socialist Programme Party (abbreviation: BSPP), there was no political opposition whatsoever. Visas for foreigners were introduced (but the possibility of movement was very limited), the activity of the media was severely restricted. The communications infrastructure was inadequate. The Burmese had few international contacts, some shortwave radios, but there was no television. All books and magazines entering the country were controlled. All local media were censored. ${ }^{12}$

Although in 1974, under the new Constitution, governance was entrusted to the People's Assembly, in fact it was exercised by Ne Win. This document only codified the military control over a state. ${ }^{13}$ Their policies had only exacerbated relations with ethnic minorities and led to the spread of ethnic insurrections. ${ }^{14}$ The situation became more serious in 1982 when the military completed the final exclusion of Indian and Chinese foreigners from any possibility of assuming official power. Under the Burma Citizenship Law, a three-tiered system of citizenship was established. Full citizens were those who were Burman or a member of one of the indigenous ethnic/linguistic groups or those who could prove they were descendants of residents who had lived in what was Burma in 1823 (before the start of the first Anglo-Burmese War, 1824-1826). They could be elected to office and assume government posts. One did not lose this class of citizenship by marrying a foreigner. The associate citizens, such as Indians and Chinese, were those who were born in the country after that time. And finally, the third group was composed of naturalized citizens. There was to be no dual citizenship. Then, the so-called associate citizenship could be revoked if someone were disloyal to the state "by act or speech or otherwise," or because of moral turpitude or disclosure of state secrets. This extremely discriminatory law allowed only full citizens could run for office or qualify for certain economic and governmental positions and become members of the party. Those in the two lesser categories not only could hold any bureaucratic or military positions, vote, but were also denied higher education. ${ }^{15}$ At the same time, it should be noted that the indigenous Muslim Rohingyas near the Bangladesh border were never considered as any type of citizens and were excluded from any list of ethnic groups. They have become the most deprived group in the state. ${ }^{16}$

\footnotetext{
${ }^{10}$ Ibidem.

${ }^{11}$ W. McGowan, World Policy Journal, Vol. 10, No. 2,1993, p. 47-56, http://williammcgowan.com/pdf /WorldPolicyJournal-BurmeseHell.pdf, (30.01.2020).

${ }^{12}$ D.I. Steinberg, Burma/Myanmar..., p.68.

${ }^{13}$ Constitution of Myanmar, https://www.burmalibrary.org/docs07/1974Constitution.pdf, 02.01.2020.

${ }^{14}$ Crimes in Burma, A Report by International Human Rights Clinic at Harvard Law School, p. 11.

${ }^{15}$ Burma Citizenship Law 1892, https://www.refworld.org/docid/3ae6b4f71b.html, (10.01.2020).

${ }^{16}$ D.I. Steinberg, Burma/Myanmar..., p.74.
} 
In 1974-77 there were more and more anti-government demonstrations, each time bloodily suppressed by the military junta. The dramatically deteriorating economic and political situation led to the establishment in 1988 of the so-called "8888 Nationwide Popular Pro-Democracy Protests", also known as the 8-8-88 Uprisings, the People Power Uprising, the People's Democracy Movement and the 1988 Uprising. They have conducted a series of nationwide protests, marches and civil unrest against the politics of the military junta. Initially the movement consisted of students, soon joined by monks and other social groups. ${ }^{17}$

The uprising ended on 18 September 1988 after a bloody military coup by the State Law and Order Restoration Council (SLORC). The SLORC introduced martial law, arrested thousands of demonstrators, including democracy activists and human rights defenders. In addition, the state was renamed to Myanmar, and the leader of a party National League for Democracy Party (NLD), which was gaining increasing public support, Aung San Suu Kyi was put under house arrest. ${ }^{18}$ It is assumed in primary sources that it was in fact a "military transfer of power, in a sense a "coup by consent" and it was designed to continue military control by alternative means. The previous military government that had become civilianized through the Burma Socialist Programme Party (BSPP) had economically failed. ${ }^{19}$ The SLORC announced the following objectives: to ensure law and order; safe transportation and communication; adequacy of food; housing and other essential needs and -what seems to be most important-to prepare for the holding of multi-party elections. ${ }^{20}$

And so, on 27 May 1990 parliamentary elections were held, which saw the admission of 93 political groups of 87 independent candidates. ${ }^{21}$ As David Steinberg claims, the election was not meant to form a parliamentary government, but rather to form a parliament-sized constitutional committee to draft a new constitution. ${ }^{22}$

Although much of the opposition was imprisoned or under house arrest, the military junta suffered a crushing defeat. The NLD won a landslide victory, taking approximately $60 \%$ of the popular vote and 392 seats (out of 492 ) $^{23}$ in the Burmese Constitutional Committee. However, the military junta refused to recognise the results, suppressing the protests of the supporters of democracy. ${ }^{24}$

\footnotetext{
${ }^{17}$ E. Meixler, How a failed democracy uprising set the stage for Myanmar's future, https://time.com/5360637 /myanmar-8888-uprising-30-anniversary-democracy/, (20.01.2020).

${ }^{18}$ Crimes in Burma, A Report..., p 7-11.

${ }^{19}$ D.I. Steinberg, Burma/Myanmar..., p.82.

${ }^{20}$ S. Sundararaman, From SLORC to SPDC: Political Continuity Versus Economic Change in Myanmar, https://www.idsa-india.org/an-jan10.html, 15.01.2020.

${ }^{21}$ D.I. Steinberg, Burma/Myanmar..., p. 91.

${ }^{22}$ Ibidem, p. 90-93.

${ }^{23}$ MYANMAR Parliamentary Chamber: Pyithu Hluttaw, ELECTIONS HELD IN 1990, http://archive.ipu .org/parline-e/reports/arc/2388_90.htm, (10.01.2020).

${ }^{24}$ D. Tonkin, The 1990 Elections in Myanmar: Broken Promises or a Failure of Communication?, Contemporary Southeast Asia, Vol. 29, No. 1 (April 2007), p. 33-54, https://www.jstor.org/stable/25798813 ?seq=1, (10.01.2020).
} 
With the end of the Cold War and the award of the 1991 Nobel Peace Prize to Aung San Suu Kyi ${ }^{25}$ Burma's interest in the international scene increased. In the same year the United Nations adopted its first resolution on Burma, ${ }^{26}$ and in 1992, The Human Rights Committee has expressed concern about the dramatic human rights situation in the country. ${ }^{27}$ The Special Envoy's report in 1993 identified, inter alia, human rights violations such as torture, cruel, inhumane treatment or punishment, "disappearances", arbitrary executions, unlawful arrests and detentions. ${ }^{28}$

In 1997 SLORC changed its name to the State Peace and Development Council and Burma was admitted to ASEAN. ${ }^{29}$

Despite the release of a number of political prisoners in subsequent years, the situation in the country remained tense. In 2003 Khin Nyunt became Prime Minister, who proposed to hold convention in 2004 on drafting a new democratic constitution. The convention was boycotted by the NLD. The Prime Minister was accused of corruption and removed from the office. Tensions were also growing between the SPDC and ethnic minorities. $^{30}$

As a result of the deteriorating economic and political situation, Buddhist monks initiated the so-called Saffron Revolution of 2007, bloodily suppressed by military rule. Official Burmese sources reported thirteen deaths, ${ }^{31}$ but there were probably a lot more. The United Nations has spoken of about thirty to forty victims among monks and fifty to seventy civilians, ${ }^{32}$ and Burma's Democratic Voice of nearly a hundred and forty. Many demonstrators were also detained and imprisoned (according to various sources from one thousand to even six thousand). Despite the condemnation by the United Nations authorities and numerous states, the military junta remained indifferent to it and unpunished. ${ }^{33}$

However, it has become clear to the authorities that certain changes will become necessary. Thus, a few months later, the military junta passes a new constitution. Although

\footnotetext{
${ }^{25}$ Aung San Suu Kyi Biography, https://www.nobelprize.org/prizes/peace/1991/kyi/lecture/, (10.01.2020).

${ }^{26}$ Situation in Myanmar : resolution / adopted by the General Assembly, https://www.refworld.org/docid /3b00efe1c.html, (10.01.2020).

${ }^{27}$ UN Commission on Human Rights, Situation of human rights in Myanmar, 10 March 1993, E/CN.4/ RES/1993/73, https://www.refworld.org/docid/3b00f0c520.html (15.01.2020).

${ }^{28}$ Report on the situation of human rights in Myanmar / prepared by Yozo Yokota, Special Rapporteur of the Commission on Human Rights, in accordance with Commission resolution 1992/58, https://digitallibrary .un.org/record/159740, (16.01.2020).

${ }^{29}$ Crimes in Burma. A report..., p. 12-17.

${ }^{30}$ N. Ganesan, Kyaw yin Hlaing, MYANMAR State, Society and Ethnicity, Institute of Southeast Asian Studies, Singapore, 2007, p. 24.

${ }^{31}$ K. Percy, More protesters arrested as curfew orders ignored, http://www.abc.net.au/news/2007-09-28 /more-burma-protesters-arrested-as-curfew-orders/684316, (26.06.2012).

${ }^{32}$ Myanmar: UN rights expert to probe allegations of abuses during crackdown http://www.un.org/apps /news/story.asp?NewsID=24405\&Cr=myanmar\&Cr1=\#.UkdJmhZyqYQ, (22.08.2012).

${ }^{33} 100000$ Protestors Flood Street of Rangoon in "Saffron Revolution", http://www.novinite.com/view news.php?id=85644, (26.06.2012) and Burma's Saffron Revolution is not over, http://www.ituc-csi.org /burma-s-saffron-revolution-is-not?lang=en, (26.06.2012).
} 
the junta reserved the right to guarantee a quarter of the seats in parliament and three strategic ministries (internal affairs, defence and foreign affairs), it nevertheless began a series of reforms. ${ }^{34}$

The first general parliamentary elections in twenty years were held in 2010. This event was hailed by the military junta as the first step towards democracy. However, opposition groups, including the NLD, boycotted the elections. This was because, according to the rules adopted at the time, those with convictions were not allowed to belong to political parties and thus to stand for election. Those regulations also ruled out participation in the elections of persons who married foreigners. By introducing that type of regulations, the military junta wanted to force the NLD to throw Aung San Suu Kyi out of its ranks, who was becoming increasingly popular in the country. The aforementioned laws also prohibited religious groups and officials from joining political parties, even though Buddhist monks have repeatedly advocated the introduction of democratic rule, for example during the aforementioned Saffron Revolution. ${ }^{35}$

The first civilian government was formed in March 2011, headed by Thein Sein, who was nominated by the military junta. Nevertheless, he declared that he wanted to disassociate himself from the policies of his predecessors, free political prisoners and take steps towards economic liberalisation. ${ }^{36}$

The opportunity to participate in the parliamentary elections for the NLD came in April 2012. These were by-elections in which the NLD won 43 seats. Still, the victory of the NLD can be seen as a step towards democracy. ${ }^{37}$

In 2015, elections to both chambers of parliament as well as regional and state assemblies were held. For the first time international observers were allowed to participate in the elections. Despite the rather restrictive provisions of the Military Constitution of 2008 (according to which a candidate to the parliament could not be a person who was declared bankrupt by the court, as well as a person with dual citizenship, and the voting rights were deprived of convicts, monks, bankrupts, persons who committed crimes related to the election, as well as incapacitated, foreigners and persons with double citizenship). The National League for Democracy (NLD) obtained a majority of the total seats in both the House of Nationalities and the House of Representatives of the Assembly of the Union. Similarly, the NLD also received a majority of total combined seats in the State and Regional Hluttaws, including 21 of 29 Ministers of Ethnic Affairs. Htin Kyaw, a close associate of Aung San Suu Kyi, became president the following year. She herself, under the provisions of the said constitution, could not run for office. Among other

\footnotetext{
${ }^{34}$ Bomb kills ethnic rebel, injures 4 others in Burma, http://usatoday30.usatoday.com/news/world/2008-01 -13-burma-explosion_N.htm, (26.06.2012).

${ }^{35}$ Burma law formally bars Aung San Suu Kyi from election, http://news.bbc.co.uk/2/hi/asia-pacific /8559048.stm, (22.06.2012).

${ }^{36}$ Daw Aung San Suu Kyi, http://topics.nytimes.cyom/top/reference/timestopics/people/a/daw_aung_san _suu_kyi/index.html, (26.06.2012).

${ }^{37}$ K. Olarn, Myanmar confirms sweeping election victory for Suu Kyi’s party, http://www.cnn.com/2012/04 /04/world/asia/myanmar-elections/index.html, (26.06.2012).
} 
requirements, the presidential candidate could not be a person whose closest members are foreign citizens (she was married to Michael Aris, a British citizen with whom she had two sons). ${ }^{38}$

On 30 March 2016 she became Minister for the President's Office, for Foreign Affairs, for Education and for Electric Power and Energy in President Htin Kyaw's government; later she relinquished the latter two ministries and President Htin Kyaw appointed her State Counsellor, a position similar to a Prime Minister created especially for her. The position of State Counsellor was approved by the House of Nationalities on 1 April 2016 and the House of Representatives on 5 April 2016. Aung Suu Kyi became de facto leader in 2016, in a "state counsellor" role. ${ }^{39}$

In the second half of 2016, Burmese army troops began to pacify regions in the western part of the country inhabited by the Rohingya Muslim minority. In 2018 Myanmar's military leaders were accused by the United Nations of carrying out genocide, war crimes, and crimes against humanity against Rohingya Muslims, calling for six generals to face trial at the International Criminal Court. It also accuses Aung San Suu Kyi of failing to prevent the violence. Myanmar rejects the findings. In 2018, Canadian parliamentarians, took back her honorary citizenship of the country, and Amnesty International, the Ambassador of Conscience Award "for the shameful betrayal of the values the leader of Myanmar once represented". 40

Myanmar now faces a lawsuit at the International Court of Justice (ICJ) in The Hague, and Aung San Suu Kyi has travelled to the Netherlands to fight the charges of genocide levelled against her country. ${ }^{41}$ In January 2020, the court's initial ruling ordered the country to take emergency measures to protect the Rohingya from genocide. ${ }^{42}$

According to the Myanmar Constitution of 2008 Myanmar is an independent sovereign nation. The sovereign power of the Union is derived from the citizens and is in force in the entire country. In the country "practises genuine, disciplined multi-party democratic system". In the country we are dealing with the separation of powers. The legislative power of the Union is shared among the Pyidaungsu Hluttaw, Region Hluttaws and State Hluttaws. On the other hand, the executive power of the Union is shared among the Pyidaungsu, Regions and States. The Head of the Union and the Head of Executive of the Union is the President, whereas the judicial power of the Union is shared among the

\footnotetext{
${ }^{38}$ The Myanmar Elections: Results and Implications, https://www.burmalibrary.org/docs21/ICG-2015-12-09 -the-myanmar-elections-results-and-implications-en-red.pdf, (16.01.2020) and Constitution of Myanmar... ${ }^{39}$ W. Moe, R. C. Paddock Aung San Suu Kyi Moves Closer to Leading Myanmar, https://www.nytimes.com /2016/04/06/world/asia/myanmar-aung-san-suu-kyi-state-counselor.html, (01.02.2020).

${ }^{40} \mathrm{https}: / / w w w . a m n e s t y . o r g / e n / l a t e s t / n e w s / 2018 / 11 /$ amnesty-withdraws-award-from-aung-san-suu-kyi/, (02. 02.2020).

${ }^{41}$ Myanmar's Aung San Suu Kyi Takes the Stand , https://foreignpolicy.com/2019/12/12/myanmars-aung -san-suu-kyi-takes-the-stand/, (20.01.2020).

${ }^{42}$ S. van den Berg, P. Ruma, World Court orders Myanmar to protect Rohingya from acts of genocide, https://www.reuters.com/article/us-myanmar-rohingya-world-court/world-court-orders-myanmar-to -protect-rohingya-from-acts-of-genocide-idUSKBN1ZM00H, (17.02.2020).
} 
Supreme Court of the Union, High Courts of the Regions, High Courts of the States and Courts of different levels including Courts of Self-Administered Areas. The Constitution also safeguards a number of human rights. And so, every citizen shall enjoy the right of equality, the right of liberty and the right of justice, as prescribed in this Constitution. There is also a prohibition on detaining a citizen in custody for more than 24 hours without the permission of a court. ${ }^{43}$ At the same time the state guarantees any person the right to enjoy equal rights before the law and equal legal protection. There is also a prohibition to discriminate against any kind of citizen of the state, based on race, birth, religion, official position, status, culture, sex and wealth, as well as freedom of speech and expression, freedom of assembly and association, the right to preserve one's culture and use one's goods, freedom of movement and the right to choose one's place of residence, the right to protection of privacy and security of home, property, correspondence and other communications of citizens. Although Buddhism has been recognised as a state religion, other religions are also respected, and any attempt to misuse religion for political purposes is prohibited. In addition, the Constitution guarantees the right to education, health care, the right to carry out scientific research and economic activities, prohibits human trafficking and slavery. ${ }^{44}$ It is worth noting that the Constitution does not guarantee the citizens' right to information about the government's actions. During the period of censorship, the government would not inform the public about its actions, and if it did, with discretion primarly via state-owned media. ${ }^{45}$ The exercising of human rights may be restricted in the event of states of emergency and if, in the opinion of the authorities, this would be contrary to the applicable law, security, prevalence of law and order, community peace and tranquillity or public order and morality. ${ }^{46}$

Myanmar, like many other Asian countries, rarely ratifies international human rights acts. The following have been ratified: Convention on the Elimination of All Forms of Discrimination against Women, International Covenant on Economic, Social and Cultural Rights, Convention on the Rights of the Child, Optional Protocol to the Convention on the Rights of the Child on the involvement of children in armed conflict, Optional Protocol to the Convention on the Rights of the Child on the sale of children child prostitution and child pornography, Convention on the Rights of Persons with Disabilities. At the same time there is no acceptance of individual complaints procedures as well as Acceptance of the inquiry procedure for Myanmar. ${ }^{47}$

In 2011, the Myanmar National Human Rights Commission, under the Myanmar National Human Rights Commission Law was formed with the aim of uplifting and protecting the fundamental rights of citizens included in the constitution of the Republic

\footnotetext{
${ }^{43}$ Constitution of Myanmar...

${ }^{44}$ Ibidem.

${ }^{45}$ Assessment of media development in Myanmar, IPDC The International Programme for the Development of Communication, p. 15-16, http://www.unesco.org/new/en/communication-and-information/resources /publications-and-communication-materials/publications/full-list/assessment-of-media-development-in -myanmar/, (10.01.2020).

${ }^{46}$ Constitution of Myanmar...

${ }^{47}$ UN Treaty database, https://tbinternet.ohchr.org/_layouts/15/TreatyBodyExternal/Treaty.aspx?CountryID $=119 \&$ Lang $=$ EN, $(25.02 .2020)$.
} 
of the Union of Myanmar. ${ }^{48}$ It was to be an independent body, to investigate complaints of possible human rights violations. In practice, however, its actions proved to be ineffective. Representatives of civil society accuse it, among other things, of refusing to investigate cases of the arrests of 275 civilians and the killings of six civilians by the Myanmar military in Rakhine State in 2019 or the murders of two ethnic Kachin villagers in 2018, as well as concerning protection of human rights in the cases of the performers in the Daungdohmyoset (Peacock Generation) Thangyat Troupe (thangyat is a traditional Myanmar performing art). The performers have been sued several times by the military in different jurisdictions for criticizing the military in their satirical performances. ${ }^{49}$

There are serious human rights violations in Myanmar. According to international human rights organisations, such as Human Rights Watch and Amnesty International, it is primarily the persecution of the Rohingya minority or violations of freedom of speech and expression. Civilians are endangered by the military's indiscriminate attacks, forced displacement, and aid blockages. Farmers continue to face threats and arrests for protesting unresolved confiscation claims and for farming the land they claim. ${ }^{50}$ Moreover, restrictions on the rights to freedom of expression, association, and peaceful assembly continued. Authorities continued to arbitrarily arrest and detain human rights defenders as well as other peaceful activists. Impunity persisted for perpetrators of human rights violations and crimes under international law. Myanmar retains the death penalty in law, but hasn't executed for at least 10 years..$^{51}$

Myanmar has 56,590,071 inhabitants (July 2020 est.) and is therefore the $25^{\text {th }}$ largest country in the world in terms of population. According to the government, the country is inhabited by 135 ethnic minorities, of which the largest group are: Burman (Bamar) 68\%, Shan 9\%, Karen 7\%, Rakhine 4\%, Chinese 3\%, Indian 2\%, Mon 2\%, other $5 \% .^{52}$ The majority of the society are the Buddhist $87.9 \%$, the reset are: Christian $6.2 \%$, Muslim 4.3\%, Animist $0.8 \%$, Hindu $0.5 \%$, other $0.2 \%$, none $0.1 \%$ (2014 est). As of December 2019, Muslims probably make up less than $3 \%$ of Burma's total population due to the large outmigration of the Rohingya population since $2017 .{ }^{53}$

In 2014 the first national census in 30 years was conducted in Myanmar. According to it, its population was 51486253 people. However, it should be noted that the Rohingya minority, whose number in the country, according to the rights groups, is approximately 800000 , was deliberately omitted from the census. ${ }^{54}$ The vast majority of the population

\footnotetext{
${ }^{48}$ Republic of the Union of Myanmar. Myanmar National Human Rights Commission, http://www.mnhrc .org.mm/en/about/about-the-commissioner/, (11.02.2020).

${ }^{49}$ Z. Z. Htwe, Myanmar Human Rights Commission Ineffective, Needs Reform: Civil Society Groups, https://www.irrawaddy.com/news/burma/myanmar-human-rights-commission-ineffective-needs-reform -civil-society-groups.html, (11.02.2020).

${ }^{50}$ Burma, https://www.hrw.org/world-report/2019/country-chapters/burma, (13.01.2020).

${ }^{51}$ Myanmar, https://www.amnesty.org/en/countries/asia-and-the-pacific/myanmar/, (13.01.2020).

${ }_{52}^{52} \mathrm{CIA}$, https://www.cia.gov/library/publications/resources/the-world-factbook/geos/bm.html, (14.01.2020).

${ }^{53}$ Ibidem.

${ }^{54}$ P. Heijmans, Myanmar's Controversial Census https://thediplomat.com/2014/09/myanmars-controversial -census/, (17.01.2020).
} 
lives in rural areas (in 2014 - urbanised areas were inhabited by 14,877,943 people, and rural areas - 35,401,957). The largest age group were people between 15 and 64 years of age (there are $32,982,768$ of them). The number of children under 14 years of age was $14,399,569$, and people in the group of 65 years of age and more $-2,897,563$. The majority of the population over 15 years of age could write and read (of which $92.6 \%$ were men and $86.9 \%$ women). In the age group 5-17, 64.3\% attended school, $24.8 \%$ did not attend and $10.9 \%$ never went to school. In 2014 the unemployment rate was 4.0 (3.9 men and 4.1 women). ${ }^{55}$

According to the Constitution of Myanmar the economic system of the Union is market economy system. Burma's economic growth rate recovered from a low increase under $6 \%$ in 2011 but has been unstable and reached the rate between $6 \%$ and $7.2 \%$ during the past few years. Burma's vast natural resources and young labour force have the potential to attract foreign investment in the energy, garment, information technology, and food and beverage sectors. The government is focusing on accelerating agricultural productivity and land reforms, modernizing and opening the financial sector, and developing transportation and electricity infrastructure. The government has also taken steps to improve transparency in the mining and oil sectors. Despite these improvements, living standards have not improved for the majority of the people residing in the countryside. Burma remains one of the poorest countries in Asia - approximately $26 \%$ of the country's 51 million people live in poverty. The isolationist policies and economic mismanagement of previous governments have left it with poor infrastructure, endemic corruption, underdeveloped human resources, and inadequate access to capital, which will require a major engagement to reverse. The Burmese government has been slow to address impediments to economic development such as unclear land rights, a restrictive trade licensing system, an opaque revenue collection system, and an obsolete banking system. ${ }^{56}$

Corruption in Myanmar is a serious problem the country needs to deal with. According to Transparency International, in 2019 Myanmar was on 130 position out of 180 countries in the ranking. The number of the points received was 29/100 (a country or territory's score indicates the perceived level of public sector corruption on a scale of 0 (highly corrupt) to 100 (very clean) to 29 . On the other hand, in 2018, the country ranked 132 out of 180 assessed countries and had a score of $29 / 100 .^{57}$

\section{Situation OF THE MEdia UNTIL THE END OF 2011}

During the reign of the military junta, the media, as has been mentioned earlier, were under strict control. Although the 1974 Constitution affirmed that "every citizen shall have freedom of speech, expression and publication to the extent that such freedom is not contrary to the interests of the working people and socialism", but in practice the military regime of General Ne Win interpreted the article so restrictively as to prevent

\footnotetext{
552014 Population and Housing Census of Myanmar - Data Sheet, https://myanmar.unfpa.org/sites/default /files/pub-pdf/Census\%20Data\%20Sheet\%20-\%20ENGLISH_0.pdf, (25.01.2020).

${ }^{56}$ CIA, https://www.cia.gov/library/publications/the-world-factbook/geos/bm.html, (25.01.2020).

${ }^{57}$ Transparency International, https://www.transparency.org/country/MMR\#, (20.01.2020).
} 
the expression of any dissenting opinion through the mass media. All journalistic work, and even poetry or films, were carefully analysed and selected before they could be made public. Interestingly, not only were works in which the authors dared to criticise the actions of the government banned, but also the so-called "bad news", for example about some natural disasters and sometimes football matches that were lost by national teams. ${ }^{58}$

The most important and restrictive documents undermining the freedom of media that have been in force during this period (some of them even to this day), include: the Printers and Publishers Registration Law 1962, ${ }^{59}$ the Emergency Provisions Act 1950, ${ }^{60}$ the State Protection Law 1975, ${ }^{61}$ The Television and Video Act, ${ }^{62}$ The Motion Picture Law, ${ }^{63}$ The Computer Science Development Law, ${ }^{64}$ The Official Secrets Act $1923,{ }^{65}$ The Burma Wireless Telegraphy Act 1933, ${ }^{66}$ Martial Law Order 3/89, ${ }^{67}$ Wide Area Network Establishment and Service Providing order No. 3/2002, ${ }^{68}$ the Electronic Transactions Law. ${ }^{69}$

And so, the Printers and Publishers Registration Law of 1962 imposed an obligation on the printers and publishers to submit all books and publication to Press Scrutiny Board to obtain permission for possible publication. The Commission had very broad powers, it could demand implementing relevant amendments and even a ban and destruction of the whole publication. This prevented publishers from carrying out activities that could expose them to enormous costs. It was also difficult to predict exactly what content could be criticised by that committee. Therefore, in 1995 Memorandum to All Printers and Publishers Concerning the Submission of Manuscripts for Scrutiny, Issued by the Printers' and Publishers' Central Registration Board was announced, according to which it was not permissible to publish any material containing a) anything detrimental to the Burmese socialist programme; b) anything detrimental to the ideology of the state; c) anything detrimental to the socialist economy; d) anything which might be harmful to national

\footnotetext{
${ }^{58}$ Myanmar Profile, http://www.bbc.co.uk/news/world-asia-pacific-12991727, (26.06.2012).

${ }^{59}$ The Printers and Publishers Registration Law 1962, https://www.burmalibrary.org/mm/1962-printers-and -publishers-registration-law-english, (10.02.2020).

${ }^{60}$ The Emergency Provisions Act 1950, https://www.burmalibrary.org/docs19/1950-Emergency_Provisions Act-en.pdf, (10.02.2020).

${ }^{\overline{6} 1}$ The State Protection Law 1975, https://www.burmalibrary.org/docs6/State_Protection_Law+amendment .pdf, (10.02.2020).

${ }^{62}$ The Television and Video Act, https://www.burmalibrary.org/docs6/Television_and_Video_Law.pdf, (10.02.2020).

${ }^{63}$ The Motion Picture Law, https://www.burmalibrary.org/docs15/1996-SLORC_Law1996-09-Motion\%20 Picture\%20Law-en.pdf, (20.02.2020).

${ }^{64}$ The Computer Science Development Law, https://www.burmalibrary.org/en/the-computer-science -development-law-slorc-law-no-1096-english, (17.02.2020).

${ }^{65}$ The Official Secrets Act 1923, http://www.asianlii.org/mm/legis/laws/bosa1923206/, (16.02.2020).

${ }^{66}$ The Burma Wireless Telegraphy Act 1933, http://www.asianlii.org/mm/legis/code/bwta1934280.pdf, (16.02.2020).

${ }^{67}$ Martial Law Order 3/89, https://www.burmalibrary.org/docs/LIOB_02.pdf, (18.02.2020).

${ }^{68}$ T. Oo, M.M Than, Myanmar, http://www.digital-review.org/uploads/files/pdf/2009-2010/chap-32 myanmar.pdf, (30.03.2020).

${ }^{69}$ The Electronic Transactions Law, https:/www.myanmartradeportal.gov.mm/en/legal/216, (13.02.2020).
} 
solidarity and unity; e) anything which might be harmful to security, the rule of law, peace and public order; f) any incorrect ideas and opinions which do not accord with the times; g) any descriptions which, though factually correct, are unsuitable because of the time or circumstances of their writing; h) any obscene (pornographic) writing; i) any writing which would encourage crimes and unnatural cruelty and violence; j) any criticism of a non-constructive type of the work of government departments; k) any libel or slander of any individual. As can be seen, the rules on permitted content in the publication remained unclear. Their harshness was enhanced by an amendment to the Printers and Publishers Registration Law, introduced in 1989, which increased the penalties which could be imposed on those convicted of breaching the law. Under this, anyone who failed to comply with any rules or regulations framed under the law could, for example, be imprisoned for up to seven years and fined up to 30,000 kyats.

In practice, the Emergency Provisions Act of 1950 had little in common with states of emergency in practice. This law made it an offence, punishable with imprisonment for up to seven years, to commit any act which "violates or infringes upon the integrity, health, conduct and respect of State military organisations and government employees towards the ... government", "causes or intends to spread false news about the government" or "causes or intends to disrupt the morality or the behaviour of a group of people or the general public." However, there was no indication as to what exactly would be the characteristics of such information to be considered inappropriate and detrimental to the interests of the State.

Then, the State Protection Law of 1975 also called as the Law to Safeguard the State Against the Dangers of Those Desiring to Cause Subversive Acts, allowed a sentence of up to five years' imprisonment as well as detention without trial. Such a punishment could affect anyone who, in the opinion of the authorities, could in any way (for example by disseminating certain information) threaten the sovereignty, security or order of the State. ${ }^{70}$ There was still no commentary or jurisprudence, allowing for example to foresee what kind of the publication may be prohibited. Such vague regulations gave the military junta enormous scope for interpretation, often dependent on their authoritarian decisions. What is interesting, in 1994 the SLORC announced that they would be justified in holding anyone arrested under the law for a total of 6 years, arguing that the period of five years specified in Section 14 was in addition to the period of one year initially allowed under the section.

The Television and Video Act of 1995 on the other hand required organisations and the public to obtain an approval of the Ministry of Communications to own TV and video equipment. ${ }^{71}$ The 1996 Motion Picture Law imposed an obligation to obtain a permission from the Myanmar Cinema Company to make films and then censor them if, in the opinion of the authorities, there is a need to do so.

\footnotetext{
${ }^{70}$ The State Protection Law, https://www.burmalibrary.org/docs6/State_Protection_Law+amendment.pdf, (02.02.2020).

${ }^{71}$ Acts of Oppression. Censorship and the law in Burma, http://www.article19.org/data/files/pdfs/publications /burma-acts-of-oppression.pdf, (28.09.2013).
} 
The Official Secrets Act, adopted back in 1923, which provided for a prison sentence of up to two years and/or a fine for possession of any information and documents which, in the opinion of those in power, could threaten national security, relations with other states or public order, was still in force. Then, Martial Law Order 3/89 provided regulations that any publication, without the prior consent of the Ministry of the Interior and Religious Affairs, is a criminal offence. One can also mention here The Burma Wireless Telegraphy Act of 1933, adopted back in 1933, which required a permission to possess any kind of equipment enabling remote data transmission. At the turn of 1995/96 the military junta supplemented this document by obtaining permission to have a fax and/or a computer.

Subsequent documents refer to the content published on the Internet. And so, the Computer Science Development Law of 1996 required the user to obtain a prior consent of the Ministry of Communications to own and use a computer. Wide Area Network Establishment and Service Providing order No. 3/2002 concerned creating a computer web. And finally, the Electronic Transactions Law of 2004 provided penalties for anyone who commits any offense by using electronic transactions technology.

Also, other acts which clearly restrict freedom of expression and media were in force. One can mention here Section 122, Penal Code of Burma, ${ }^{72}$ The Law Protecting the Peaceful and Systematic Transfer of State Responsibility and the Successful Performance of the Functions of the National Convention Against Disturbances and Oppositions ${ }^{73}$ as well as The Unlawful Associations Act 1908. ${ }^{74}$

The first of the aforementioned made it an offence to commit treason against the government established by law. This offence was punishable with death, or with imprisonment for life. Over the years, it has been used against all people who have merely expressed peaceful dissent against the authorities.

The second of the aforementioned documents made it an offence, among other things, to: a) incite, demonstrate, deliver speeches, make oral or written statements and disseminate [them] in order to undermine the stability of the state, community peace and tranquillity and prevalence of law and order; b) incite, deliver speeches, make oral or written statements and disseminate [them] in order to undermine national reconsolidation; c) disturb, destroy, obstruct, incite, deliver speeches, make oral or written statements and disseminate [them] in order to undermine, belittle and make people misunderstand the functions being carried out by the National Convention for the emergence of a firm and enduring Constitution; or d) draft and disseminate the Constitution of the state without lawful authorization. Each of these acts were made punishable with imprisonment for between three and 20 years and a possible fine, as were attempts or abetment of them.

72 Penal Code of Burma, https://www.burmalibrary.org/docs17/1861-Penal_Code-ocr-en+bu.pdf, (09. 02.2020).

${ }^{73}$ The Law Protecting the Peaceful and Systematic Transfer of State Responsibility and the Successful Performance of the Functions of the National Convention Against Disturbances and Oppositions, https:// www.burmalibrary.org/en/the-law-protecting-the-peaceful-and-systematic-transfer-of-state-responsibility -and-the-successful, (10.02.2020).

${ }^{74}$ The Unlawful Associations Act 1908, http://www.asianlii.org/mm/legis/code/uaa1908255/, (11.02.2020). 
One also cannot forget The Unlawful Associations Act 1908 which, though primarily used to deny freedom of association, was often applied in a manner that has impacted adversely on freedom of expression. This law, among other things, made it an offence, punishable with imprisonment for between two and three years and a possible fine, to have contact with any organization which the Burmese authorities declared illegal.

Passing a new constitution in 2008, which guaranteed freedom of speech and the media did not in fact change anything. The authorities have not repealed any of the documents mentioned above, which, after all, made it impossible to use the freedom of speech and media given on paper.

Any kind of pretext, such as the publication of St. Valentine's Day wishes, was enough for a journalist who disobeyed the military junta to end up in one of forty-three prisons, sometimes for many years..$^{75}$

Among the victims, the following ones can be mentioned: Maung Thura, Thet Zin and U Sein Win Maung, Hla Min, Htay Win, Thida Aye, Ma Thida. The number of all victims during this period is practically impossible to estimate. Zarangar (actually) is a popular Burmese comedian, film actor, and a film director, a critic and a political prisoner of the Burmese military government Zarganar was banned indefinitely from performing publicly or participating in any kind of entertainment related work. He was arrested in 2008 for speaking to foreign media about the situation of millions of people left homeless after a cyclone devastated the Irrawaddy Delta and then sentenced to 59 years in prison, convicted of "public order offenses", under the criminal code. Then, Thet Zin and U Sein Wing Maung were accused of possessing documents relating to human rights in Burma and the "Saffron Revolution", which were seized during a search of the offices. ${ }^{76}$ Draconian law would often be used to arrest and imprison members of the NLD party, as in 1990, when Hla Min, Htay Win, Thida Aye and others were arrested for attempting to publish, without permission, a report of the NLD's historic Gandhi Hall meeting. The writer Ma Thid was sentenced to 20 years' imprisonment for distributing anti-government leaflets. ${ }^{77}$

The persecution of journalists lasted until the end of 2010, and even longer still in 2011, after the first media reform was launched. Before it had been introduced there were more than 150 private dailies and magazines in the country. However, they could only publish content that had previously been approved by the Media Commission. Some tried to smuggle some democratic content during the first general parliamentary elections. They did so with varying degrees of success, but each time they were liable to fines, imprisonment, suspension or closure of the editorial office. ${ }^{78}$ The authorities

\footnotetext{
75 Burmese media spring, https://reliefweb.int/sites/reliefweb.int/files/resources/burmese_spring.pdf, (28.09.2013).

${ }^{76}$ Editor and office manager of Myanmar Nation charged under press law, https://rsf.org/en/news/editor-and -office-manager-myanmar-nation-charged-under-press-law, (05.02.2020).

${ }^{77}$ UNION OF MYANMAR (BURMA) @Arrests and trials of political prisoners January-July 199, https:// www.amnesty.org/download/Documents/196000/asa160101991en.pdf, (10.04.2020).

${ }^{78}$ Burmese media combating censorship, http://en.rsf.org/birmanie-report-burma-combating-censorship-22 -12-2010,39134.html, (28.09.2013).
} 
also published their own newspapers, namely: "Kyemon", "Myanma Alin", "New Light of Myanmar" or "The Yadanabon". Electronic media (television and radio) were under the complete control of the ruling authorities. ${ }^{79}$ The Internet, although existing, was also subject to control. ${ }^{80}$

The services of foreign broadcasters such as BBC, RFA, VOA and DVB could be received in the country. Although they broadcast in Burmese, their activities were strictly controlled. Many international journalists were notoriously being refused the right to enter the country. ${ }^{81}$

Some journalists from Myanmar managed to escape abroad, mostly to Thailand. But they did not remain passive. At least two significant initiatives are worth mentioning here. In 1992 the Democratic Voice of Burma was established, with two offices in Chiang Mai, Thailand and Oslo, Norway. The Democratic Voice of Burma used both radio, satellite television and the Internet. Their popularity was great, TV and radio was received by about five million people in Burma, and the website was visited by about ten thousand users a day, mainly from the United States and Singapore. In addition, on May 3, 2011, they launched a worldwide campaign for the release of all journalists in Burma. ${ }^{82}$ About one hundred and twenty journalists, who also found refuge in northern Thailand, founded the Burmese Media Association. They ran a website that provided daily information and articles on the human rights situation in Burma. Their role was and is invaluable. It was thanks to them that the world was informed about the suppression of the Saffron Revolution or the authorities' complete ignorance of the tragedy caused by cyclone Nargis in $2008 .^{83}$

\section{Media Situation SINCE 2012}

The reforms announced in 2011 finally gave some hope for respecting media freedom. In the same year, the authorities announced amnesty for dozens of political prisoners, including the blogger Zarganar, Sein Win Maung, editor of Myanmar Nation and three reporters of the Democratic Voice of Burma ${ }^{84}$ One of the most important steps towards media freedom was the abolition of the obligation of prior censorship, as well as the obtaining operating licences by the print media. However, they still had to be registered

\footnotetext{
79 May Thaw, Broadcasting options expanding, http://www.mmtimes.com/feature/electronic/e09.htm, (28.09.2013).

${ }^{80}$ Internet cafe in Myanmar, http://www.myanmar2day.com/myanmar-information/2009/02/internet-cafe-in -myanmar/, (28.09.2013).

${ }^{81}$ Freedom of the Press. Report 2007, http://www.freedomhouse.org/report/freedom-press/freedom-press -2007?page=251\&year=2007, (28.09.2013).

${ }^{82}$ S. Roughneen, Burmese Media Launch Campaign to Free Jailed Reporters, http://mediashift.org/2011/05 /burmese-media-launch-campaign-to-free-jailed-reporters130/, (30.03.2020).

${ }^{83}$ Burmese media spring...

${ }^{84}$ Ibidem.
} 
with the Ministry of Information. ${ }^{85}$ Internet censorship in Myanmar was largely abolished in $2014 .^{86}$

Two laws were passed in 2014 to regulate the issues of the printed media, namely The Printing and Publishing Enterprises Law (PPEL) ${ }^{87}$ and the News Media Law. ${ }^{88}$ The Broadcasting Law of Myanmar ${ }^{89}$ was passed in 2015.

The Printing and Publishing Enterprises Law (PPEL) replaced Printers and Publishers Registration Law of 1962. In fact, the provisions of the Act explicitly referred to the 1962 Printers and Publishers Registration Law. However, the penalties provided for in the new law were not as severe as in the 1962 Act. The prison sentence was reduced from seven years to six months and the fine was limited to approximately $\$ 12,000$ for the owners of the publications. Article 7 prohibited the publication of any publication "a) expressing subject matters which may cause harm to an ethnic group or among the ethnic groups, or those which may insult other religions; b) provoking for the purpose of deteriorating the rule of law or encouraging mass violence; c) expressing nudity; d) encouraging and stimulating crimes, cruel behavior, violence, gambling and the act of committing crimes using opium and abusive drugs; e) publishing expressions and texts which are against and violate the provisions of the Constitution and other legislations."

The News Media Law guarantees for example "freedom from censorship to express, publish, or distribute freely as part of rights and privileges granted to every citizen in compliance with regulations stated in the national constitution", the rights and freedoms of media workers, and stipulates that the media is the fourth state authority.

In accordance with Article 4, media employees have the right "a) to freely criticize, point out or recommend operating procedures of the legislative, the executive and judiciary in conformity with the constitution, b) to investigate, publish, broadcast information and related opinions to which every citizen is entitled in accordance with rules and regulations, c) to reveal issues relating to rights and privileges lost by the citizen, d) to collect information, to be provided with accommodation and to enter into certain offices, departments and organizations in accordance with regulations of relevant departments or organizations". If media personnel operate in war zones or during riots or demonstrations, they cannot be arbitrarily detained and their equipment cannot be

\footnotetext{
${ }^{85}$ Assessment of media development..., p. xvii.

${ }^{86}$ Ibidem, p. 42.

${ }^{87}$ The Printing and Publishing Enterprises Law, https://www.burmalibrary.org/mm/printing-and-publishing -enterprise-law-bill-english, (07.02.2020).

${ }^{88}$ The News Media Law, http://www.myanmar-law-library.org/law-library/laws-and-regulations/laws /myanmar-laws-1988-until-now/union-solidarity-and-development-party-laws-2012-2016/myanmar-laws -2014/pyidaungsu-hluttaw-law-no-12-2014-news-media-law-burmese.html, (06.02.2020).

${ }^{89}$ The Broadcasting Law of Myanmar, http://www.myanmar-law-library.org/law-library/laws-and-regu lations/laws/myanmar-laws-1988-until-now/union-solidarity-and-development-party-laws-2012-2016 /myanmar-laws-2015/pyidaungsu-hluttaw-law-no-53-2015-broadcasting-law-burmese.html, (05.02.2020).
} 
destroyed or confiscated. Furthermore, they may ask relevant entities to guarantee their safety and security. Additionally, they shall be entitled to obtain unclassified information from the activities of non-governmental organisations, as well as entities operating from public funds. Employees are obliged to observe professional ethics. Investigative journalists may conduct an investigation, without disclosing their personal information, with the consent of the relevant publisher and the approval of the proposed action. Possible confiscation, destruction of materials is allowed only by court judgment. ${ }^{90}$ At this point it is worth mentioning the protection of information sources. According to the Media Code of Conduct (COC) of 2014, "Media outlets have a moral obligation to protect confidential sources of information and to respect confidences knowingly and willingly accepted in the course of their work. This Code supports that obligation." However, the document serves as an industry standard only. Journalists themselves are unable to protect sources of information. ${ }^{11}$

Article 12 of The News Media Law established Myanmar's News Media Council, which is primarily responsible for monitoring the media and ensuring that high quality media is maintained. It is an independent organisation, consisting of employees of various media, as well as scientists.

Another law mentioned above is The Broadcasting Law of Myanmar. It imposes an obligation to obtain a licence for broadcasting media. However, the Act does not address issues relating to the digital terrestrial television transition. The Act established the National Broadcasting Council, which is also an independent organisation with similar functions to Myanmar's News Media Council.

Despite these changes, it should be noted that the legal system for the media in Myanmar is outdated. Although the Emergency Provision Act of 1950 and the State Protection Act of 1975 were repealed in 2016, the state still has laws in force that undermine media freedom and journalists face legal consequences for their actions.

We may not forget that the development of media is also influenced by changes in telecommunications law. In 2013, the Telecommunications Law $^{92}$ was passed, under which the telecommunications industry was privatized. Myanmar now has three national telecommunications providers. Privatisation of the sector has resulted in a sharp drop in SIM card prices, making mobile phone ownership accessible to a large part of the population and thus increasing Internet access. It is also worth mentioning the Competition Law of 2015, which prohibits monopoly practices or various regulations concerning the possibility of advertising in the media.

\footnotetext{
${ }^{90}$ The News Media Law...

${ }^{91}$ Assessment of media development..., p.22.

${ }^{92}$ The Telecommunications Law, http://www.myanmar-law-library.org/law-library/laws-and-regulations /laws/myanmar-laws-1988-until-now/union-solidarity-and-development-party-laws-2012-2016/myanmar -laws-2013/pyidaungsu-hluttaw-law-no-31-2013-telecommunication-law-burmese.html, (05.02.2020).
} 
Changes in media legislation have caused a real boom in the publishing of printed media. However, problems with maintaining their continuity quickly emerged. State-owned media have a clear competitive advantage over private media, both in media production and distribution. There are media that are strongly supported by political parties, such as the National League for Democracy's D-Wave Journal, or the Union Solidarity and Development Party's Union Daily. Ethnic media are likely to represent the interests and views of their associated armed wings, rather than the Bamar central state. However, there is no accurate publicly available data on printed media. Similarly, data on circulation and sales is difficult to come by. According to UNESCO print media cannot adequately provide for the information needs of all segments of society, most notably poor and rural populations. Due to the country's weak road infrastructure, print media circulation is mostly limited to urban and peri-urban areas. ${ }^{93}$ In Myanmar many citizens rely on broadcasters for their information and entertainment needs. All broadcasters in the country are either state-owned or joint-ventures between the State and private companies. Private, public and community broadcasters do not exist in Myanmar yet. Myanmar has two stateowned broadcasters. MRTV operates under the Ministry of Information and Myawaddy operates under the Ministry of Defence. Both of these broadcasters provide TV and radio broadcasting. Moreover, Myanmar has seven joint-venture radio stations. Another medium through which many people in Myanmar access news and information is TV broadcasting. Joint-venture broadcasters offer subscription services, therefore they are not affordable for some groups of the society. Both state broadcasters (MRTV and Myawaddy) offer a freeto-air channel. Their channels are more commonly viewed, particularly in rural areas. ${ }^{94}$

The Internet is becoming more and more popular. Most major print publications in Myanmar have a web version, however there is a heavy focus on social media. The list of the most popular websites consists of: Facebook 7 Day, ${ }^{95}$ Eleven, BBC Burmese, Irrawaddy Burmese, VOA Burmese, Mizzima Burmese, MRTV-4 and DVB TV (random order). ${ }^{96}$

There are associations and journalist unions in Myanmar, such as Myanmar Journalist Association. The Foreign Correspondents' Club of Myanmar, The Myanmar Journalists' Union (MJU), the Myanmar Journalists' Association (MJA), and the Myanmar Journalists' Network (MJN). ${ }^{97}$

The state media as Myanmar Ahlinn, The Mirror and The Global New Light of Myanmar all take in news from state feeds around the country. This may come direct from

\footnotetext{
${ }^{93}$ Assessment of media development ..., p. 60-61.

${ }^{94}$ Ibidem, p. 19.

${ }^{95}$ In Myanmar, Facebook is the Internet and the Internet is Facebook, https://seasia.yale.edu/myanmar -facebook-internet-and-internet-facebook

${ }^{96}$ E. Lehmann-Jacobsen, Myanmar audience study 2018. Myanmar's media from an audience perspective, IMS-Fojo, September 2018 https:/www.mediasupport.org/wp-content/uploads/2018/07/Myanmar-audi ence-study-2018_online.pdf, p.15-18.

97 Journalist unions in Myanmar in joint campaign for press freedom, https://www.mediasupport.org /journalist-unions-in-myanmar-join-forces-in-campaign-to-curb-restrictive-media-laws/, (10.01.2020).
} 
Myanmar News Agency (MNA), which falls under the Ministry of Information, or from Myawaddy, which is a military-run news service. State media also retains subscriptions to Press Trust of India, Reuters and Tass. International wire agencies such as AFP, AP and Reuters have fully-staffed bureaus in Yangon. Other international news organisations retain correspondents or stringers. ${ }^{98}$

\section{Recommendations for Myanmar to guarantee ReSPeCt FOR MEdia FREEDOM}

The state of respect for freedom of expression and media freedom in Myanmar is not satisfactory and the authorities should take steps to improve the situation as soon as possible. The most important, however not the only, recommendations to Myanmar on media freedom will be presented below:

- $\quad$ Signing and ratifying international human rights documents guaranteeing freedom of expression and media freedom, such as the International Covenant on Civil and Political Rights and the International Convention on the Elimination of all Forms of Racial Discrimination,

- Introduction of amendments to the Constitution of 2008, aimed at strengthening guarantees for media freedom and introducing the citizen's right to information. In 2019,99 steps were taken to introduce the citizen's right to information, but this issue has not yet been resolved. It should be remembered that a such right must be enforceable.

- Immediate repeal all laws violating media freedom,

- $\quad$ Promoting the positive aspects of respect for media freedom by the authorities and undertake the fight against censorship and hate speech,

- $\quad$ Ensuring proper interpretation of the regulations - only independent courts can properly interpret laws which restrict press freedom

- $\quad$ Consulting bills with journalists and other legal entities with legal interest in guaranteeing and respecting media freedom as well as ensuring their participation in the legislative process

- $\quad$ Creating conditions that will encourage the emergence of new media and enable these and existing media to stay in business, such as providing them with financial support for start-ups or reducing tax rates to ensure media pluralism and diversity.

- Media must have fair and equal access to distribution channels and technical infrastructure (for example, radio frequencies, transmission cables, satellites) or

\footnotetext{
${ }^{98}$ Myanmar newspapers and news sites, https://www.w3newspapers.com/myanmar/, (05.01.2020).

${ }^{99}$ Myanmar: Guarantee the right to free expression in the constitution, https://www.hrw.org/news/2019/04 /11/myanmar-guarantee-right-free-expression-constitution, (05.02.2020).
} 
commercial (newspaper distributors, postal or other delivery services). Moreover, media ownership and economic influence over media must be made transparent.

- $\quad$ Government, parliament and the courts must be open to the media in a fair and equal way,

- Guaranteeing equal and fair access to the media for all political parties and social groups,

- Enabling the media to communicate information and ideas on all matters of public interest. However, they must not exceed certain limits, in particular those relating to respect for the reputation and rights of others and the confidentiality of certain information. It should be noted that freedom of journalism also means the possibility of a certain exaggeration or even provocation. Otherwise, the media would be prevented from fulfilling an important role, namely that of a public observer

- State officials shall not be protected against criticism and journalists should not be imprisoned, or media outlets closed, for such critical comments. The limits of acceptable criticism are wider for politicians and their public activities than for private individuals. Politicians consciously and inevitably expose themselves to reactions to every word they say and everything they do today and did in the past. They must therefore be more tolerant even of more violent attacks. However, this does not mean that someone, just because he or she is a public figure, can be slandered with impunity without being able to defend his or her good name. In such situations, however, the extent of the justified protection of his or her good name should always be determined in confrontation with the value of public debate

- Guaranteeing the protection of journalistic sources, as this is one of the basic conditions for media freedom. Without such protection, the essential role and place of the media in a democratic society has to be weakened. However, the right to protection of information sources is not unlimited, in particularly justified cases where public considerations will be so important as to oblige a journalist to disclose his or her source, but this will not be considered a violation of international human rights standards,

- Journalists must be protected against physical threats or attacks because of their work. Police protection must be provided when requested by journalists who feel threatened. Prosecutors and courts must deal adequately, and in a timely manner, with cases where journalists have received threats or have been attacked. The absence of such a guarantee may make it entirely impossible for the media to be a platform for democratic discourse

- $\quad$ Penal laws against incitement to hatred or for the protection of public order or national security must respect the right to freedom of speech. If penalties are imposed, they must respect the requirements of necessity and proportionality. If a politically motivated application of such laws can be implied from the frequency and the intensity of the penalties imposed, media legislation and practice must be changed 
- Immediate and unconditional release of all media representatives who have carried out their duties, in accordance with international standards on media freedom. If these standards are trespassed, guaranteeing a fair trial for media representatives,

- Allowing foreign journalists as well as human rights observers to enter the country. The refusal to enter and to produce material on the situation in Myanmar cannot be justified on the grounds of fear of producing material that could show the state in a light that is unfavourable to the authorities

- $\quad$ Strengthening of a system of media self-regulation including a right of reply and correction or voluntary apologies by journalists

- $\quad$ Obligation for the media to comply with their own professional codes of conduct

- Development of the media education system as well as professional training and workshops for the media

- $\quad$ Monitoring respect for media freedom by independent institutions established by the media

- Annual publication by the government of a reliable and accurate report on the situation of media freedom in Myanmar.

\section{Conclusion}

From the time of the military coup in 1962 until the creation of Thein Sein's civilian government there was no respect for freedom of the media and freedom of speech in Myanmar. The media were under the strict control of the military junta. The laws in force at the time completely paralysed the activities of the media. Journalists were often persecuted, sentenced to prison terms or fines, and the media were suspended or even closed down. The situation was to change dramatically in 2011. Thein Sein promised to break with the previous policies of his predecessors, release political prisoners and take steps to guarantee media freedom. One of them was the abolition of prior censorship. Several legislation acts were repealed, however many laws that undermined media freedom remained in force. The media market revived, although many media had difficulty keeping up with it. The broadcast media continue to be dominated by the state authorities. Internet media are becoming increasingly popular, although not everyone, for technical reasons, has unrestricted access to it. Journalists continue to be punished for informing the public about issues of great importance to them, such as the persecution of the Rohingya minority. Myanmar remains among the countries where respect for media freedom, according to the Press Freedom Index, is of particular concern to the international community. Respect for media freedom in Myanmar is possible, but this requires immediate action. Otherwise, the media will not be able to fulfil their most important role as a public observer (watchdog). The most important of these are the repeal of the draconian law, which undermines media freedom, the provision of comprehensive support for private media, and the development of training for journalists and other media professionals. 


\section{BiBLIOGRAPHY}

\section{Legal acts}

European Convention of Human Rights, https://www.echr.coe.int/Documents/Convention _ENG.pdf, (30.03.2020).

Constitution of Myanmar, https://www.burmalibrary.org/docs07/1974Constitution.pdf, 02.01.2020.

Penal Code of Burma, https://www.burmalibrary.org/docs17/1861-Penal_Code-ocr-en+ bu.pdf, (09.02.2020).

The Broadcasting Law of Myanmar, http://www.myanmar-law-library.org/law-library /laws-and-regulations/laws/myanmar-laws-1988-until-now/union-solidarity-and -development-party-laws-2012-2016/myanmar-laws-2015/pyidaungsu-hluttaw -law-no-53-2015-broadcasting-law-burmese.html, (05.02.2020).

The Burma Citizenship Law 1892, https://www.refworld.org/docid/3ae6b4f71b.html, (10.01.2020).

The Burma Wireless Telegraphy Act 1933, http://www.asianlii.org/mm/legis/code/bwta 1934280.pdf, (16.02.2020).

The Computer Science Development Law, https://www.burmalibrary.org/en/the-computer -science-development-law-slorc-law-no-1096-english, (17.02.2020).

The Electronic Transactions Law, https:/www.myanmartradeportal.gov.mm/en/legal /216, (13.02.2020).

The Emergency Provisions Act 1950, https://www.burmalibrary.org/docs19/1950 -Emergency_Provisions_Act-en.pdf, (10.02.2020).

The Law Protecting the Peaceful and Systematic Transfer of State Responsibility and the Successful Performance of the Functions of the National Convention Against Disturbances and Oppositions, https://www.burmalibrary.org/en/the-law -protecting-the-peaceful-and-systematic-transfer-of-state-responsibility-and-the -successful, (10.02.2020).

The Martial Law Order 3/89, https://www.burmalibrary.org/docs/LIOB_02.pdf, (18.02.2020).

The Motion Picture Law, https://www.burmalibrary.org/docs15/1996-SLORC_Law1996 -09-Motion\%20Picture\%20Law-en.pdf, (20.02.2020).

The News Media Law, http://www.myanmar-law-library.org/law-library/laws-andregulations/laws/myanmar-laws-1988-until-now/union-solidarity-and-develop ment-party-laws-2012-2016/myanmar-laws-2014/pyidaungsu-hluttaw-law-no-12 -2014-news-media-law-burmese.html, (06.02.2020).

The Official Secrets Act 1923, http://www.asianlii.org/mm/legis/laws/bosa1923206/, (16.02.2020). 
The Printers and Publishers Registration Law 1962, https://www.burmalibrary.org/mm /1962-printers-and-publishers-registration-law-english, (10.02.2020).

The Printing and Publishing Enterprises Law, https://www.burmalibrary.org/mm/printing -and-publishing-enterprise-law-bill-english, (07.02.2020).

The State Protection Law 1975, https://www.burmalibrary.org/docs6/State_Protection _Law+amendment.pdf, (10.02.2020).

The Telecommunications Law , http://www.myanmar-law-library.org/law-library/laws-and -regulations/laws/myanmar-laws-1988-until-now/union-solidarity-and-develop ment-party-laws-2012-2016/myanmar-laws-2013/pyidaungsu-hluttaw-law-no -31-2013-telecommunication-law-burmese.html, (05.02.2020).

The Television and Video Act, https://www.burmalibrary.org/docs6/Television and _Video_Law.pdf, (10.02.2020).

The UnlawfulAssociationsAct 1908, http://www.asianlii.org/mm/legis/code/uaa1908255/, (11.02.2020).

Wide Area Network Establishment and Service Providing order No. 3/2002.

\section{Jurisdiction}

Case of Handyside v. The United Kingdom (Application no. 5493/72), https:// hudoc.echr.coe.int/eng\#\{“itemid“":[“001-57499”]\}, (25.01.2020).

Case of Bladet Tromsø and Stensaas V. Norway (Application no. 21980/93), https:// hudoc.echr.coe.int/eng\#\{“itemid“":[“001-58369”]\}, (25.01.2020).

\section{Books}

JAMES H., Security and Sustainable Development in Myanmar, Routledge Taylor \& Francis Group, London and New York, 2005.

SHELDON G.W, Encyclopaedia of Political Thought, New York: Facts on File, Inc, 2001.

STEINBERG D.I., Burma/Myanmar what everyone needs to know, Oxford University Press, 2010.

\section{Articles/ Chapters in books}

BERG VAN DER S., RUMA P., World Court orders Myanmar to protect Rohingya from acts of genocide, https:/www.reuters.com/article/us-myanmar-rohingya-world -court/world-court-orders-myanmar-to-protect-rohingya-from-acts-of-genocide -idUSKBN1ZM00H, (17.02.2020).

Bomb kills ethnic rebel, injures 4 others in Burma, http://usatoday30.usatoday.com/news /world/2008-01-13-burma-explosion_N.htm, (26.06.2012).

DAWAUNGSANSUUKYI, http://topics.nytimes.cyom/top/reference/timestopics/people /a/daw_aung_san_suu_kyi/index.html, (26.06.2012). 
GANESAN N., KYAW H.Y, MYANMAR State, Society and Ethnicity, Institute of Southeast Asian Studies, Singapore, 2007.

HEIJMANS P., Myanmar's Controversial Census https://thediplomat.com/2014/09 /myanmars-controversial-census/, (17.01.2020).

HTWE Z.Z., Myanmar Human Rights Commission Ineffective, Needs Reform: Civil Society Groups, https://www.irrawaddy.com/news/burma/myanmar-human-rights -commission-ineffective-needs-reform-civil-society-groups.html, (11.02.2020).

LEWIS J.R, Freedom of the Press [w:] J.R. Lewis, C. Skutsch (red.), The Human Rights Encyclopedia, Armonk, NY: Sharpe Reference, 2001.

MCGOWAN W., World Policy Journal, Vol. 10, No. 2 (Summer, 1993), p. 47-56, http:// williammcgowan.com/pdf/WorldPolicyJournal-BurmeseHell.pdf, (30.01.2020).

MEIXLER E., How a failed democracy uprising set the stage for Myanmar's future, https://time.com/5360637/myanmar-8888-uprising-30-anniversary-democracy/, (20.01.2020).

MOE W., Paddock R.C, Aung San Suu Kyi Moves Closer to Leading Myanmar, https:// www.nytimes.com/2016/04/06/world/asia/myanmar-aung-san-suu-kyi-state -counselor.html, (01.02.2020).

Myanmar's Aung San Suu Kyi Takes the Stand, https://foreignpolicy.com/2019/12/12 /myanmars-aung-san-suu-kyi-takes-the-stand/, (20.01.2020).

OLARN K., Myanmar confirms sweeping election victory for Suu Kyi's party, http://www .cnn.com/2012/04/04/world/asia/myanmar-elections/index.html, (26.06.2012).

PERCY K., More protesters arrested as curfew orders ignored, http://www.abc.net.au /news/2007-09-28/more-burma-protesters-arrested-as-curfew-orders/684316, (26.06.2012).

ROUGHNEEN S., Burmese Media Launch Campaign to Free Jailed Reporters, http:// mediashift .org/2011/05/burmese-media-launch-campaign-to-free-jailedreporters130/, (30.03.2020).

SUNDARARAMAN S., From SLORC to SPDC: Political Continuity Versus Economic Change in Myanmar, https://www.idsa-india.org/an-jan10.html, (15.01.2020).

THAW M., Broadcasting options expanding, http://www.mmtimes.com/feature/electronic /e09.htm, (28.09.2013).

TONKIN D., The 1990 Elections in Myanmar: Broken Promises or a Failure of Communication?, Contemporary Southeast Asia, Vol. 29, No. 1 (April 2007), p. 33-54, https://www.jstor.org/stable/25798813?seq=1, (10.01.2020).

100000 Protestors Flood Street of Rangoon in „Saffron Revolution”, http://www.novinite .com/view_news.php?id=85644, (26.06.2012).

\section{Reports}

Acts of Oppression. Censorship and the law in Burma, http://www.article19.org/data/files /pdfs/publications/burma-acts-of-oppression.pdf, (28.09.2013). 
Assessment of media development in Myanmar, IPDC The International Programme for the Development of Communication, http://www.unesco.org/new/en/com munication-and-information/resources/publications-and-communication-mater ials/publications/full-list/assessment-of-media-development-in-myanmar/, (10.01.2020).

Burma, https://www.hrw.org/world-report/2019/country-chapters/burma, (13.01.2020).

Burmese media combating censorship, http://en.rsf.org/birmanie-report-burma-combating -censorship-22-12-2010,39134.html, (28.09.2013).

Burmese media spring, https://reliefweb.int/sites/reliefweb.int/files/resources/burmese _spring.pdf, (28.09.2013).

Crimes in Burma, A Report by International Human Rights Clinic at Harvard Law School.

Freedom of the Press. Report 2007, http:/www.freedomhouse.org/report/freedom-press $/$ freedom-press-2007?page $=251 \&$ year $=2007,(28.09 .2013)$.

Lehmann-Jacobsen E., Myanmar audience study 2018. Myanmar's media from an audience perspective, IMS-Fojo, September 2018 https://www.mediasupport.org /wp-content/uploads/2018/07/Myanmar-audience-study-2018_online.pdf.

Report on the situation of human rights in Myanmar / prepared by Yozo Yokota, Special Rapporteur of the Commission on Human Rights, in accordance with Commission resolution 1992/58, https://digitallibrary.un.org/record/159740, (16.01.2020).

The Burmese Way to Socialism, https://www.burmalibrary.org/sites/burmalibrary.org /files/obl/docs/The_Burmese_Way_to_Socialism.htm, (10.02.2020).

Union of Myanmar (Burma) @Arrests and trials of political prisoners January-July 199, https://www.amnesty.org/download/Documents/196000/asa160101991en.pdf, (10.04.2020).

\section{The Internet}

Amnesty International, https://www.amnesty.org/en/latest/news/2018/11/amnesty-with draws-award-from-aung-san-suu-kyi/, (02.02.2020).

Amnesty International https:/www.amnesty.org/en/countries/asia-and-the-pacific/myanmar/, (13.01.2020).

Aung San Suu Kyi Biography, https://www.nobelprize.org/prizes/peace/1991/kyi/lecture/, (10.01.2020).

Burma law formally bars Aung San Suu Kyi from election, http://news.bbc.co.uk/2/hi/asia -pacific/8559048.stm, (22.06.2012).

Burma's Saffron Revolution is not over, http:/www.ituc-csi.org/burma-s-saffron -revolution-is-not?lang=en, (26.06.2012).

CIA, https://www.cia.gov/library/publications/resources/the-world-factbook/geos/bm .html, (14.01.2020). 
Editor and office manager of Myanmar Nation charged under press law, https://rsf.org /en/news/editor-and-office-manager-myanmar-nation-charged-under-press-law, (05.02.2020).

In Myanmar, Facebook is the Internet and the Internet is Facebook, https://seasia.yale.edu /myanmar-facebook-internet-and-internet-facebook, (10.04.2020).

Internet cafe in Myanmar, http://www.myanmar2day.com/myanmar-information/2009/02 /internet-cafe-in-myanmar/, (28.09.2013).

Journalist unions in Myanmar in joint campaign for press freedom, https://www .mediasupport.org/journalist-unions-in-myanmar-join-forces-in-campaign-to -curb-restrictive-media-laws/, (10.01.2020).

Myanmar: Guarantee the right to free expression in the constitution, https://www.hrw .org/news/2019/04/11/myanmar-guarantee-right-free-expression-constitution, (05.02.2020).

Myanmar newspapers and news sites, https:/www.w3newspapers.com/myanmar/, (05.01.2020).

Myanmar Profile, http://www.bbc.co.uk/news/world-asia-pacific-12991727, (26.06.2012).

Myanmar: UN rights expert to probe allegations of abuses during crackdown http://www .un.org/apps/news/story.asp?NewsID $=24405 \& \mathrm{Cr}=$ myanmar $\& \mathrm{Cr} 1=\# . \mathrm{UkdJmh}$ ZyqYQ, (22.08.2012).

Myanmar Parliamentary Chamber: Pyithu Hluttaw, ELECTIONS HELD IN 1990, http:// archive.ipu.org/parline-e/reports/arc/2388_90.htm, (10.01.2020).

Republic of the Union of Myanmar. Myanmar National Human Rights Commission, http://www.mnhrc.org.mm/en/about/about-the-commissioner/, (11.02.2020).

Situation in Myanmar : resolution / adopted by the General Assembly, https://www.ref world.org/docid/3b00efe1c.html, (10.01.2020).

The Myanmar Elections: Results and Implications, https://www.burmalibrary.org/docs21 /ICG-2015-12-09-the-myanmar-elections-results-and-implications-en-red.pdf, (16.01.2020).

Transparency International, https://www.transparency.org/country/MMR\#, (20.01.2020).

UN Commission on Human Rights, Situation of human rights in Myanmar, 10 March 1993, E/CN.4/RES/1993/73, https://www.refworld.org/docid/3b00f0c520.html (15.01.2020).

UN Treaty database, https://tbinternet.ohchr.org/_layouts/15/TreatyBodyExternal/Treaty .aspx? CountryID=119\&Lang=EN, (25.02.2020).

2014 Population and Housing Census of Myanmar - Data Sheet, https://myanmar.unfpa .org/sites/default/files/pub-pdf/Census\%20Data\%20Sheet $\% 20-\% 20$ ENGLISH _0.pdf, (25.01.2020).

Received: March $10^{\text {th }} 2020$

Accepted: May $12^{\text {th }} 2020$ 